\title{
Tecnologización de actividades preventivas en el sistema de preparación de futuros profesores: estrategia para mejorar la calidad de la educación universitaria
}

\section{Technologization of preventive activities in the system of preparing future teachers: a strategy for improving the quality of university education}

\author{
Kondrashov Nikolay Mykolayovych ${ }^{1}$, Kondrashova Katerina Gennadyevna ${ }^{2}$, Chuvasov
} Mykhailo Olegovich $^{3 a}$, Volkova Nataliia Valentynivna ${ }^{4}$, Slyusarenko Nina Vitaliivna ${ }^{5}$

\author{
Cherkasy National University, Cherkasy, Ukraine ${ }^{123}$ \\ Kryvyi Rih State Pedagogical University, Kryvyi Rih, Ukraine ${ }^{4}$ \\ Kherson State Pedagogical University, Cherson, Ukraine ${ }^{5}$ \\ D ORCID ID https://orcid.org/0000-0002-3411-22091 \\ ORCID ID https://orcid.org/0000-0003-0705-8857² \\ ORCID ID https://orcid.org/0000-0002-2024-90953 \\ ORCID ID https://orcid.org/0000-0002-4864-86534 \\ ORCID ID https://orcid.org/0000-0002-9215-5936
}

Recibido: 26 de febrero de 2021

Aceptado: 29 de junio de 2021

\begin{abstract}
The article reveals the theoretical foundations of the technologization of preventive activity in the system of training future teachers for the chosen profession as a strategy for improving the quality of modern higher pedagogical education. The purpose of the article is the theoretical substantiation and testing of the effectiveness of technologization of preventive activities in the system of improving the quality of training of teaching staff. With the help of a set of research methods (questioning, testing, observation, modeling of event-role situations, pedagogical experiment, analysis of the results of preventive activities of students, methods of mathematical statistics), the resource possibilities of technologization of preventive activities in ensuring positive dynamics of the level of readiness of future teachers for professional activity and reliability the results obtained. It has been established that through the use of various types, forms, teaching methods, operating with content based on didactic interaction in the "teacher students" system, the quality of the educational process of the university is achieved. The effectiveness of various educational technologies as one of the means of technologizing preventive activities in the system of training future teachers for creative professional work is shown.
\end{abstract}

Keywords: prevention, preventive activity, technologization of training, educational technologies. 


\section{Resumen}

El artículo revela los fundamentos teóricos de la tecnificación de la actividad preventiva en el sistema de formación de futuros docentes para la profesión elegida como estrategia para mejorar la calidad de la educación pedagógica superior moderna. El objeto del artículo es la fundamentación teórica y la comprobación de la eficacia de la tecnificación de las actividades preventivas en el sistema de mejora de la calidad de la formación del profesorado. Con la ayuda de un conjunto de métodos de investigación (cuestionamiento, prueba, observación, modelado de situaciones de eventos y roles, experimento pedagógico, análisis de los resultados de las actividades preventivas de los estudiantes, métodos de estadística matemática), las posibilidades de recursos de la tecnificación de las actividades preventivas. en asegurar una dinámica positiva del nivel de preparación de los futuros docentes para la actividad profesional y la confiabilidad de los resultados obtenidos. Se ha establecido que mediante el uso de diversos tipos, formas, métodos de enseñanza, operando con contenidos basados en la interacción didáctica en el sistema "docente - alumnos", se logra la calidad del proceso educativo de la universidad. Se muestra la efectividad de diversas tecnologías educativas como uno de los medios de tecnificar las actividades preventivas en el sistema de formación de futuros docentes para el trabajo profesional creativo.

Palabras clave: prevención, actividad preventiva, tecnificación de la formación, tecnologías educativas.

\section{Introduction}

The problems of the quality of training future teachers for professional activity in modern conditions are especially relevant and acquire a personality-oriented and practiceoriented nature, which is quite consistent with the strategy of technologization of the process of training future specialists on the principles of preventive activity in the university education system. At the same time, an important requirement is the mastery by future teachers of the theoretical foundations of pedagogical prevention and educational technologies, the methodology of their use in the practice of the educational process. Smantser (2014), and Rangelova (2014) studies focus on the theoretical substantiation of the means of preventing the consolidation of negative habits in the behavior of a person, concretizing the functions of prevention in preparing future teachers for professional activity. According to these authors, the effectiveness of pedagogical actions to prevent deviating behavior of schoolchildren depends on how much the teacher has mastered the theoretical foundations of preventive activity, its technology and realized the laws governing the formation of personality selfawareness. "In self-consciousness, the feelings of personal responsibility, the desire for selfregulation and self-affirmation are manifested to the greatest extent" (p. 31)

Since one of the goals of ensuring the positive dynamics of the quality of training future teachers for professional activity is the conscious self-development of each participant in the educational process, prevention and a technological tool for organizing training are one of the 
most effective means of achieving quality education in a university. Rogers (1994) noted that every child has a developmental impulse, the need to fully realize his natural potential. But he can realize his natural forces with mutual understanding and relationship on the part of the teacher and the people around him. The preventive activity of the teacher is the factor that has a positive effect on the development of the natural forces of the individual and on the quality of the educational process.

The quality of training a specialist in the field of pedagogical work is ensured not by the simple participation of the student in the educational process, but by the formation of a positive attitude towards the chosen profession, professional interests and values, the need to creatively fulfill professional duties. The attention of scientists is increasingly focused on substantiating the theoretical foundations of the formation of a teacher's professional image, searching for additional resources that have a positive effect on the dynamics of the quality of education. Amonashvili (1984) argued that a teacher should "learn to give children the joy of learning, laugh and rejoice in their lessons with the children" (p. 194), build humane relations with children, and see a personality in each student. Preventive activity allows in pedagogical practice to realize the attitude towards each student as a person - self-sufficient, original, unique.

Recently, an increasing number of researchers are trying to determine the essence of preventive activity as a factor influencing the results of pedagogical work. Fedotenko (2007) believes that: "the preventive activity of a teacher presupposes a high level of his competence, technological and technical readiness associated with self-realization, with communication management, with a targeted impact on a child, a group of children" (p. 75). In her opinion, an orientation towards prevention in education is able to provide a situation of personal growth and personal development in the educational process, preservation of his physical and moral health.

Kondrashova (2014) sees the possibilities of preventive activity in changing the way of pedagogical actions. She considers timely assistance and pedagogical support in the educational process and professional development of students to be the object of the teacher's preventive actions. According to her, "the knowledge obtained at school does not automatically lead to the humanization of the individual, the formation of a stable moral and social position, national identity. All this is impossible without the organization of a purposeful pedagogical process, the basis of which must be the preventive activities of the teacher "(p.108).

Many researchers solve the problem of the quality of training of future teachers by using new technologies in the educational process. The technologization of the process of managing the quality of training students for professional activity was studied by Yelnikova (2008), 
Ryabova (2008), Marmaza (2007), Kondrashova (2014), Chuvasova (2017), Kucheriavyi (2020) etc. Problems of training technologies and knowledge assimilation were investigated by Burton (2004), Paris (2001), Reisch, Flexner (2017), Austin (2018), Vance (2018), Ingvarson (1998), Clement (2018), Öqvist (2018), Toshio (2008).

Afanasyev (1999) focuses on the technological aspect of the pedagogical process, on the spiritual basis of learning. "During the technologicalization of the educational process," he says, "it is important to acquire not only specific skills and abilities, but also knowledge that is aimed at the middle, to achieve order in the soul, which means knowledge of each subjectscientific knowledge and giving it a humanitarian character." (p.40). Bech (2001) sees the modernization of higher education students in the use of various pedagogical technologies, the effectiveness of which "depends on the methodological basis that directly determines the nature of their practical development" (p. 169).

Dakovska (2015) sees the success of solving the problem in the use of various technologies: projective and interactive, presentation technologies, knowledge testing and online technologies, which, in her opinion, ensures the achievement of the planned results of pedagogical practice. Sysoeva (2001) considers technology as a means of activating the educational process, transforming its participants from an object into a subject of learning, as a tool for developing creative abilities and preparing them for creative activity.

For the other hand, Japanese scientists solve the problem of the quality of education by means of technologizing the educational process, which reduces stress in learning, contributes to the formation of the independence of a person's thinking. Sugie (2004) argues that interactive technologies can improve the skills of independent mastery of knowledge, ensure their quality and successful application in practice. Shiota (1989) believes that group technologies help to form humane relations, trust between participants in the educational process, which ensures a successful solution to educational problems. Mason (1994) gives preference to cooperative technologies that determine the personality-oriented nature of education, its quality and the ability to respond flexibly to all processes that take place in society.

This situation deserves a positive assessment of the opinion of scientists about the need for purposeful and systematic training of future teachers for preventive activities. It is in the process of training based on the principles of prevention that the teacher's activity, efficiency, and readiness to change not only the circumstances of the pedagogical process, but also to rebuild his own activity, professional behavior are formed. 


\section{Methodology}

The quality of higher education is ensured by the priority position of prevention in preparing future teachers for professional activities. Therefore, the object of our research is the activity organized on the principles of prevention, and the subject is the preparation of future teachers for preventive activity by means of its technologization. The purpose of the research is theoretical substantiation and experimental verification of the effectiveness of technologization of training future teachers for preventive activities.

The participants in the study were students from 1-4 courses (544 people) and teachers (40 people), all of them from Bogdan Khmelnytsky Cherkasy National University, Cherkasy, (Ukraine), from Kryvyi Rih State Pedagogical University, Kryvyi Rih, (Ukraine), and from Kherson State Pedagogical University, Kherson (Ukraine). The research was conducted in the period from 2016 to 2020 .

Testing the effectiveness of solving the assigned tasks in the study was carried out using diagnostic techniques (a technique for diagnosing the development of a professional orientation of a personality, a technique for studying difficulties in the work of students, a technique for diagnosing the formation of preventive actions of future teachers). The identification of the main indicators of students' readiness for preventive activities was carried out using the following methods:

a) the orientation of the individual to mastering preventive activities (questionnaires, conversations, observation, solving pedagogical problems);

b) the need for preventive actions (modeling, business games, psychological sketches);

c) independence (situation-problems, situations-exercises, situations-assessments);

d) professional position (creative tasks, competitions, creative projects);

e) development of emotional and volitional qualities (communication, role, psychological and game trainings);

f) the need for self-improvement (self-assessment methods, self-characteristics, rating).

The reliability of the results obtained was checked for each indicator based on the identification of the statistical criterion x2 (chi - square) proposed by Novikov (2004). At the ascertaining and formative stages of the pedagogical experiment, according to the indicators of readiness for preventive activity, based on the use of the $\mathrm{x} 2$ criterion (chi - square), the obtained data were processed and the effectiveness of the developed model of training future teachers for preventive activity by means of technologizing the educational process was determined. The development of appropriate tools for monitoring the effectiveness of technologization of 
training future teachers for preventive activities is a logical step to ensure the quality of professional training of students in a university environment.

\section{Results}

The solution of the set tasks necessitated studying the level of preparedness of students and identifying the possibilities of technologization in overcoming the difficulties of preventive activity, which are not so rare for practicing teachers in the performance of professional functions.

For this purpose, on the basis of the Cherkassy, Kryvyi Rih and Kherson universities, a survey was conducted, during which it was revealed that the difficulties in the work of a teacher are explained by the insufficient level of their training during their studies at a higher pedagogical school.

At the stage of the ascertaining experiment, the questioning revealed difficulties in the work of the teacher. Almost $100 \%$ of teachers and $100 \%$ of students noted the lack of knowledge in preventive pedagogy and methods of preventive activity, the methodology of using personality-oriented technologies was not developed. The weak scientific and methodological support of preventive activities was indicated by $88 \%$ of teachers and $91 \%$ of students. The lack of objective methods for diagnosing the individual characteristics of students and the readiness of teachers for preventive activities were noted by $58 \%$ and $100 \%$ of teachers and, respectively, $32 \%$ and $100 \%$ of students. The need to master the technique of supporting and preventing the consolidation of bad habits of students was indicated by $100 \%$ of practicing teachers and $83 \%$ of students. $20 \%$ of teachers and $36 \%$ of students do not see the difference between preventive and corrective actions. The difference between these actions was shown by $25 \%$ of teachers and $10 \%$ of students.

Also, the survey showed that pedagogical influence prevails in the teacher-student relationship, as evidenced by $81 \%$ of teachers' answers and $91 \%$ of students. The presence of didactic interaction in the educational process was noted by $11 \%$ of teachers and $2 \%$ of students. The answers of teachers and students about pedagogical assistance and support in the educational process were ambiguous. $27 \%$ of teachers and $40 \%$ of students believe that it is needed, but only if it is needed.

A qualitative analysis of the results of the questionnaire showed that the reasons for underestimating the preparation of future teachers for preventive activities should be sought in the predominance of subject learning over student-centered learning, considering the subject as a source of information, but not as a means of personal development. 
Observation and analysis of its results allows us to say that students, like pupils, need timely help and support from the teacher (49,3\%); attention to their problems $(38,7 \%)$, respect for their position and style of activity $(29,7 \%)$, tolerance for their failures and mistakes $(18,3 \%)$. Analysis of students' answers indicates an underestimation of the personal aspect in the content of their preparation for professional activity.

Prevention in the actions of a teacher is impossible if he has an intrusive didactic manner of behaving. The data collected suggests that many of them have a mentoring tone, constant teaching and assessment of students' actions. $75 \%$ of the instructors surveyed believe that an instructive tone allows you to establish business relationships with students, not stoop to familiarity, and keep a distance in communication. In turn, students believe that rigidity in communication interferes with normal relations with the teacher, leads to isolation, lack of understanding of requirements. $67 \%$ of students note that the teacher is often angry, does not come to the rescue, often speaks offensive words. All this does not contribute to the success of preventive pedagogical activity in practice.

The collected data indicate that the main focus is on equipping future teachers with knowledge, skills, and outlined curricula and programs in accordance with the profile of the chosen specialty. The basis of the traditional educational process is often the activity that is implemented by the correctional method. The meaning of this activity is that, first, gaps and shortcomings in educational work and everyday behavior are revealed in trainees, and then, through special exercises, tasks, activities, individual measures of influence, they are eradicated.

According to the diagnostic results at the stage of the ascertaining experiment, there were no significant differences in the results of the control sections. To obtain comparative data and determine the effectiveness of the experimental program for the training of future teachers, control and experimental groups were determined. The control groups included 271 students of Kryvyi Rih and Kherson universities, who showed the best results at the stage of the ascertaining experiment, their training was carried out according to the traditional method. The experimental group consisted of 273 students of the Cherkasy University named after Bohdan Khmelnitsky, whose training was carried out according to the author's method.

With the help of $\mathrm{x} 2$ - Pearson's criterion, the hypothesis about the presence of statistically significant differences between the level of training of the control and experimental groups was tested. For the null hypothesis H0, the statement was accepted: "The level of training of students in the control and experimental groups have statistically significant differences at the stage of the ascertaining experiment." As an alternative hypothesis H1, the 
statement was taken: "At the stage of the ascertaining experiment, there are no statistically significant differences in the level of training of the control and experimental groups."

Observing students' activities and analyzing their achievements allow us to assert that teachers mainly focus on mastering the program material. At the same time, they underestimate, and sometimes ignore, purposeful work to prepare for preventive activities as an important factor in the professional development of future teachers. This can explain the prevalence of low and medium levels of preparedness of students for preventive activities.

At the initial stage of the pedagogical experiment, the initial level of preparedness of students for preventive activities in control and experimental groups was studied. The results of the diagnostic section at the ascertaining stage of the experiment are presented in table 1.

\section{Table 1}

The levels of preparedness of students for preventive activity at the stage of the ascertaining experiment

\begin{tabular}{cccc}
\hline Number of students, (\%) & \multicolumn{3}{c}{ Readiness levels } \\
\cline { 2 - 4 } & High \% & Medium \% & Low \% \\
Experimental groups (273) & 1,2 & 41,3 & 57,5 \\
Control groups (271) & 2 & 42,6 & 55,4 \\
\hline
\end{tabular}

Source: Prepared by the authors (2021)

As you can see from the table. $155,4 \%$ of student in the CG and $57,5 \%$ of the EG were characterized by a low level of preparedness for preventive pedagogical activity. The average level was observed in 42,6\% of students from the CG and 41,3\% from the EG. A high level of preparedness for preventive activity was revealed in $2 \%$ of students from the $\mathrm{CG}$ and $1,2 \%$ from the EG.

Analysis of the results of tests in the disciplines of the pedagogical cycle allows us to say that teachers do not always pay sufficient attention to the development of the attitude of future teachers to preventive activity and training of intellectual abilities, the development of initiative, independence and creativity, emotional and volitional qualities, the formation of skills of preventive activity, stimulation of the need for preparation for preventive pedagogical activity. In the work of students, actions according to the model prevail, underestimation of independent work, creative assignments, non-standard exercises. This state of affairs necessitated the development of an author's program for preparing students for preventive activities and experimental verification of its effectiveness. 
The basis of the formative stage of the pedagogical experiment was the logic of using the technologization of preparing students for preventive activity:

a) the formulation of the goal of preparing students for preventive pedagogical activity, taking into account the indicators of its main characteristics that can be diagnosed;

b) determining the intermediate goals of preparing students for preventive pedagogical activity and the stages of its implementation by specifying the identified indicators of their readiness;

c) recruitment and didactic substantiation of the preparation of students in relation to the goals;

d) the implementation of the content of training through the use of various forms, methods, means, which are provided with objective methods of quality control of the phenomenon under study.

We proceeded from the fact that preparation for preventive activity in its content combines the general (core), special (addition, taking into account the specifics of the faculty) and individual (differentiation and individualization of the pedagogical process). The content of students' preparation for preventive pedagogical activity predetermines its structure, which combines three components that differ in the nature of pedagogical knowledge: fundamental, applied and individual (see Fig. 1.).

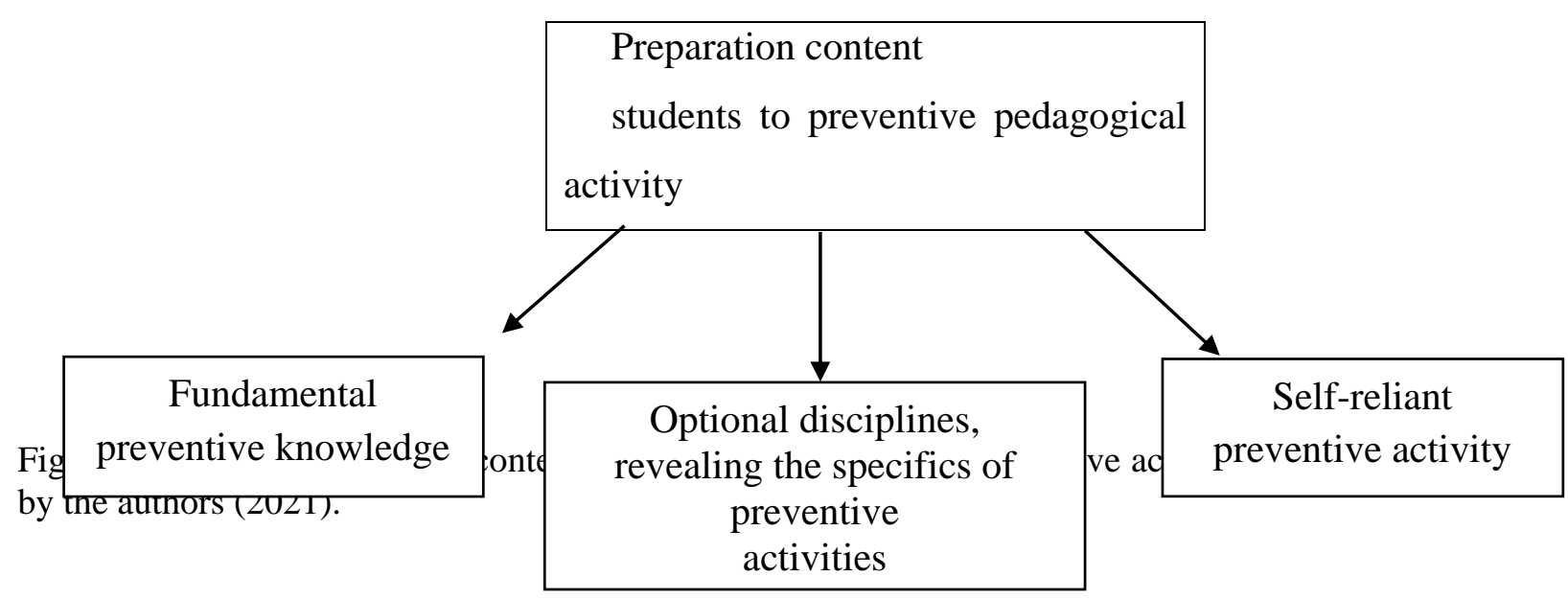

Preparing students for preventive activities necessitates updating the content of pedagogical education, the introduction of the course "Fundamentals of Preventive Pedagogy", "Workshop on solving pedagogical problems" and the training "Development of emotional and behavioral flexibility of a teacher.” These courses reveal the specifics of activities, pedagogical support and prevention of the consolidation of negative experience in children's behavior, 
concretize the means of preventing pedagogical neglect, provide systematic and purposeful work to form students' readiness for preventive activities.

The inclusion of interactive forms and methods of work in the content of the experimental program created the conditions for future teachers to improve the techniques of communicative activity, ways of cooperation and co-creation in the "teacher-student" system. In the process of dialogue, play, pedagogical and psychological sketches, discussions, analysis and playing role situations, students exchange thoughts, ideas, methods of activity. The knowledge and skills obtained during the training sessions were consolidated in the process of teaching practice. If in the classroom students learned to analyze their own mental and physical state, their actions and deeds, to manage their emotional state, then in the course of pedagogical practice they passed these skills on to students. Before the start of practice, students worked out the methodology of working with students to develop their self-esteem and self-awareness. The structure of the lesson included:

- exercises to create a positive emotional atmosphere;

- conversations in the circle of previous lessons;

- outdoor games, exercises for emotional and behavioral flexibility;

- psychodiagnostics (tests, essays, psychological sketches).

Students learned to create situations in which an independent choice of necessary actions and deeds was fixed; use technologies that protected participants in the educational process from negative experiences and the influence of others. The developed research program assumed the gradual mastering of the basic skills of pedagogical activity, carried out on the principles of prevention, and was aimed at developing the intellectual, professional and emotional-volitional qualities of students, the level of formation of which depends on the effectiveness of their preventive pedagogical activity.

At the final stage of the pedagogical experiment, a final cut of the levels of students' preparedness for preventive pedagogical activity was carried out, which confirmed the significant difference in the results of the control and experimental groups. The results indicate that a high level of preventive skills was shown by $29,3 \%$, and a low level - by $9,9 \%$ of students of Cherkasy University (EG). Only 16,8\% of students of Kryvyi Rih and Kherson Universities (KG) correspond to a high level of development of these skills and 46,5\% are characterized by a low level of their formation. A high level of independence in the implementation of preventive actions is possessed by $29,8 \%$ of students at Cherkasy University versus $16 \%$ of students in Kryvyi Rih and Kherson universities. A high level of focus on preventive activity was shown 
by $29,5 \%$, an average level $-61,3 \%$, a low level $-9,2 \%$, students of the experimental group, respectively, students of the control group showed a high level of $12,4 \%$, average $47,3 \%$, low $40,3 \%$. A high level of need for self-improvement is inherent in $46,7 \%$ of students of Cherkasy University (EG), and in the control groups this indicator is $11,5 \%$.

There was a significant increase in the number of students in the experimental group, who showed a high level of development of the need for preventive activity (by 24,7\%), motivation (by 29,0\%) and interest in preventive activity (by 32,6\%), emotionality (by 32,0\%). The expressiveness of the main indicators characterizing the features of activity based on the principles of prevention, made it possible to reveal the dynamics of the levels of preparedness of future teachers for preventive activity after the end of the pedagogical experiment.

The implementation of the experimental program on the principles of prevention and technologization of the educational process with the use of various types of information and cognitive technologies changed the dynamics of the levels of preparedness of students for preventive activities in a positive direction, which is confirmed by the data in Table 2.

\section{Table 2}

Dynamics of students' readiness levels for preventive activity according to the results of the formative experiment

\begin{tabular}{lcccc}
\hline Readiness & \multicolumn{4}{c}{ Number of students, (\%) } \\
\cline { 3 - 5 } levels & students CG & students (EG) & students CG & students(EG) \\
Low & 57,5 & 55,4 & 52,8 & 23,9 \\
Medium & 41,3 & 42,6 & 42,8 & 47,6 \\
High & 1,2 & 2 & 4,4 & 28,5 \\
\hline
\end{tabular}

Source: Prepared by the authors (2021)

From table 2 that a high level of preparedness for preventive pedagogical activity was revealed in $28,5 \%$ of students from the EG, average - in 47,6\%, low - in 23,9\%. The CG students achieved lower results: 4,4\% had a high level of preparedness for preventive activity, 42,8\% average, $52,8 \%$ - low. In the EG the indicators of the high level of readiness reached 28,5\%, the average level increased by $6,3 \%$ and the indicators of the low level decreased by $35,4 \%$. 
The level of formation among students of experimental groups of basic knowledge in the course "Fundamentals of preventive pedagogy", preventive skills significantly exceed the level of knowledge and skills of students in control groups and in comparison with the initial level at the beginning of the formative experiment. There is a noticeable positive trend in the expression of emotional and behavioral flexibility among students of the experimental groups, which allows them to more optimistically approach the solution of educational problems.

The study found that positive results are possible only if the conditions are met, namely: the dominance of the personal over the individual approach to the organization of the educational process; mastering the method of cooperation, preventing authoritarian actions and forming a democratic style of students' activity; creating situations of success; the formation of the emotional and behavioral flexibility of future teachers as an important indicator of their readiness for preventive pedagogical activity.

As shown by the observations and answers of students to the questionnaire, the most effective technologies for enhancing the cognitive activity of students in the process of preparing them for preventive activities were technologies using modeling of pedagogical situations, role and business games, debates, discussions, disputes, etc. The analysis of the final sections confirms the effectiveness of the pilot program for preparing future teachers for preventive activities in specially created conditions. In the studies of scientists from Bulgaria (Rangelova, 2012), Belarus (Smantser, 2014), Ukraine (Nichugovska, 2019), various aspects of the problem we are investigating have been confirmed.

Bulgarian professor Rangelova (2012, p. 16) explains the reason for the emerging difficulties among students by underestimating preventive activities in their preparation. She gives the data of the survey. Bulgarian students (37\%) note that teachers rarely show respectful attitude in the process of interaction with them: they show benevolence $(49,5 \%)$, attention $(44,7 \%)$, empathy $(72,7 \%)$, lack of mutual understanding, contact $(57,1 \%)$. Quite rightly, scientists consider interaction in the "teacher - students" system as the basis for preventive pedagogical activity. Rangelova (2012) explains the underdevelopment of self-discipline among students $(46,2 \%)$, a sense of responsibility $(38,5 \%)$ and initiative $(36,4 \%)$ by the underestimation of preventive activities in preparing future teachers for practical work ( p. 17). These data confirm the need for systematic training of students for the preventive pedagogical activities of the university. Smantser (2014) focuses on the humanization of relationships in the educational process, noting that in practice the authoritarian style of communication with students prevails (p. 252). The scientist explains the unpreparedness for preventive actions of 
future teachers by the lack of systematic preparation of students for preventive pedagogical activities in a university.

As shown by the observations and answers of students to the questionnaire, the most effective technologies for enhancing the cognitive activity of students in the process of preparing them for preventive activities were technologies using modeling of pedagogical situations, role and business games, debates, discussions, disputes, etc. The effectiveness of technologies in preparing future teachers for professional activities is confirmed by Nichugovska (2019), she experimentally proved the need for the phased use of educational technologies, of their various types: contextual science technology, case method technology, technology for designing an individual educational route, etc. (p. 248).

With the help of a set of research methods (questionnaires, testing, observation, modeling of event-role situations, pedagogical experiment, analysis of the results of preventive activities of students, methods of mathematical statistics), the resource possibilities of technologization of preventive activity in ensuring positive dynamics of the level of preparedness of future teachers for professional activity and experimentally the reliability of the results obtained has been confirmed.

The technologization of pedagogical training is a set of actions, operations, techniques, the consistent implementation of which will provide knowledge of the basics of preventive pedagogy, the development of preventive skills, mastery of various information and cognitive technologies, forms and methods of working with students on the principles of pedagogical support and prevention of their consolidation in experience, behavior of negative habits. The data obtained allow us to assert that the goal and objectives projected in the course of the study have been achieved.

\section{Discussion}

The resolution of this problem necessitated the development of some aspects that would combine: 1) theoretical substantiation of preventive activities in improving the quality of the educational process; 2) disclosing the possibility of technologizing it through the use of technologies based on the principles of prevention in practice. An attempt to fill this gap prompted to explore the possibilities of technologization of preventive pedagogical activity as a means of improving the quality of pedagogical education.

Analysis of pedagogical practice in various types of educational institutions revealed significant shortcomings in the organization of the educational process and underestimation of the systematic work on the formation of a professional image that meets the requirements that 
modern society imposes on teaching staff. The main reason is that students have fragmentary knowledge about professional functions, about their professional capabilities and abilities and are completely unprepared to use them in practice. The problem is that the knowledge gained by students does not become the basis for developing competent strategies in practical activity, they do not always master modern technologies focused on the preventive nature of pedagogical activity. Underestimation of the technologization of the educational process and the low level of preparedness of future teachers for preventive activities negatively affect the quality of their professional work.

An attempt to fill this gap prompted to explore the possibilities of technologization of preventive pedagogical activity as a means of improving the quality of pedagogical education. Preventive activity is determined by objective and subjective factors, it is a kind of pedagogical process, it has a goal, principles, forms, methods and means of organization and educational technologies, is a priority in the system of socialization of the individual and preparing him for life and work in society.

Preventive activity as a means of forming a system of subjective relationships is the main internal regulator of personality behavior. So, prevention in the system of preparing future teachers for professional activity is a means of developing personal potential in the educational process through the implementation of its principles in various types of educational work. According to Glasser (1991), the meaning of preventive activity is that the pedagogical process is an attribute of a person, a place where its participants can openly express their thoughts based on their life experience and observations.

These conclusions are confirmed by the works of other authors (Molyako, 1989; Rangelova, 2012; Smantser, 2014) who believe that "strict normativity interferes with normal human relationships, leads to difficulties in emotional self-expression: the teacher knows how to feel in different situations, but often cannot realize that he really is feels at the moment" (p. 43). These scientists focused on working with children of antisocial behavior, with a negative reaction to the demands of teachers to observe moral and ethical norms of behavior.

Prevention helps the teacher to avoid ineffective actions not only in relation to children with deviant behavior, but also to prosperous ones, who in difficult situations of school life also need the help and support of the teacher. Preventive pedagogical actions actualize, encourage self-movement and self-development of the internal forces and capabilities of students. Therefore, future teachers at the university must master the methodology and technology of preventive activity. 
In pedagogical practice, the correctional method predominates, which does not take into account individuality, inclinations and potencies, personality traits and capabilities. The teacher's actions, his methods of influence do not come from the study of the subjective psychological properties of the personality of students, but from the objective content of educational information and actions to be learned or trained. In this regard, the correctional method is indifferent to the individual. Such an approach to teaching and upbringing, according to Kondrashova (2014), "breaks down" rather than develops the personality and does not naturally realize its individual characteristics, inclinations and potencies.

This study shares the position of Kondrashova (2004) that the basis of the organization of preventive pedagogical activity is made up of personality-oriented, creative-activity, competence-based and technological approaches. With the help of these approaches, the individual trajectory of the development of the professional image of the future teacher and his subjective experience of creatively solving educational problems as an important source of professional development and career growth in the professional sphere are realized. At the same time, taking into account the age and individual capabilities of students, reliance on creative forces and abilities, activity and independence of actions, humanization of relations in the "teacher - students" system based on the principle of pedagogical interaction, cooperation and co-creation are especially significant. When involving students in various types of activities (pedagogical, project, research, etc.), it is necessary to provide students with the right to choose the type of activity, additional disciplines and courses, the opportunity to work according to individual educational programs. In accordance with their professional interests, cognitive needs, values and attitudes, the student has the right to choose the form of organizing the educational process, methods of solving educational problems, and a position in achieving the planned results.

One cannot but agree with the statements of Rangelova (2012) and Smantser (2014) that prevention orients the educational process towards the inner world of a person, the specifics of the chosen profession and communication, motives, needs, attitudes and its values. The predominance of subject-methodological knowledge, given from the outside, not subject to reflection, reinforces an adaptive position in future teachers, focuses on the performing type of activity, a correctional plan. The basis for overcoming the existing contradiction in the training of pedagogical personnel is the change of the paradigm of pedagogical activity from corrective actions of the teacher to preventive methods of work. The predominance of correction over prevention in teaching practice does not always effectively influence the preparation of future 
teachers for the creative fulfillment of professional functions. Therefore, the search for means of preparing future teachers for preventive activities is most relevant today.

Such a means today is the technologization of the training of pedagogical personnel. The technologization of training contributes to the creation of a creative educational environment, enhancing the position of students in professional development and formation. Technologization of the educational process is a "world" of technology. Karmin and Novikova (2004) state: "Appropriate organization of human activity involves the selection of the necessary means and methods of action, planning and execution of the sequence of operations. This organizational side of human activity determines its technology" (p. 134). Shiyanov (1999) believes that technology is a clear scientific prediction and reproduction of guaranteed success of actions - a scientific design and accurate reproduction of harmonious pedagogical actions (p.250). Sharing the views of these authors on the technologicalization of the preparation of future teachers for practical activities, it should be noted that today special importance is given to technologies based on the principles of prevention.

Technologization is considered by the authors (Kondrashov, 2020; Sysoeva, 2001; Panfilova, 2009; Marmaza, 2007) as a model of the educational process, in which the goal and the achievement of a specific result are predicted - the self-developing personality of a specialist through the use of various types, forms, teaching methods, operating with content based on didactic interaction in the "teacher - students" system. This model allows the future teacher to see not only the subject, but also the operational side of the acquired knowledge, a specific procedure for actions, pedagogical tools, techniques and methods, forms of prevention in the educational process. Only the forms of educational activity lend themselves to technologization: proven material, the teacher's actions in solving problems, stimulating students' actions, setting on the final result, interaction between the teacher and students, activity in achieving the predicted result. The form is an object of different technologies using a variety of means, methods and techniques of the teacher's actions. Dakovska (2015), Kondrashova (2001), Chuvasova (2017), Öqvist (2018) focus on the use of various technologies in the educational process (educational, informational, cognitive, electronic and etc.). However, as practice has shown, the use of technologies is considered by most authors as a means of ensuring the quality of assimilation of knowledge and mastering practical skills and abilities of correctional activity. Unfortunately, the possibilities of technologization in preparing future teachers for preventive activities have not yet received the proper attention of researchers. We proceed from the fact that the use of various technologies provides an opportunity for each student to master the methodology for performing preventive actions and self-development of 
professional properties and qualities necessary for the successful implementation of preventive activities.

The analysis of scientific literature has shown that, despite significant achievements in the theoretical substantiation of the problem under study, its reserves in raising the level of future teachers to professional activity remain not yet revealed. Therefore, in the course of the study, attention was focused on the study of the level of preparedness of students for preventive activities and the use of different technologies as a means of ensuring the quality of their preparation for the use of the principles of prevention in pedagogical activity.

\section{Conclusions}

Thus, in the course of the study, the goal of technologizing preventive activity as an important resource for improving the quality of training future teachers for professional activity has been achieved. It has been experimentally confirmed that the quality of training students for preventive activities is determined by: a) preparation of students in the mode of development of their own personality; b) goal-setting, i.e. orientation towards personality as a subject of the pedagogical process; c) awareness and assimilation of the theoretical foundations of preventive pedagogy; d) mastering the methodology and technology of preventive activity; e) timely diagnostics of students' readiness for professional activity, opportunities for prevention and technologization as means of ensuring the quality of the educational process in the university system.

Prevention in the training of future teachers through the technologization of its foundations creates conditions for the formation of a pedagogical worldview, ethical and aesthetic views of teachers, the search for innovative approaches aimed at ensuring the quality of pedagogical education. The conducted research has confirmed the effectiveness of technologization of preventive activity as an important means of improving the quality of training future teachers for professional activity.

\section{References}

Amonashvili S. A. (1984). The upbringing and educational function of assessing the teaching of schoolchildren. Moscow. https://hum.edu-lib.com/szbrannoe/amonashvili-sh-avospitatelnaya-i-obrazovatelnaya-funktsiya-otsenki-ucheniya-shkolnikov-onlayn

Afanasyev Y. N., Strogalov A. S., \& Shekhovtsev S. P. (1999) On universal knowledge and the new educational environment. Moscow. Retrieved from https://istina.ipmnet.ru/publications/book/12306304/ 
Atanasova-Popova, S. (2016). Preventive aspects of family upbringing: the focus on the emotional self-regulation of adolescents. Challenges to modern upbringing. Sofia, Bulgaria: St. Kliment Ohridski. https://research.uni-sofia.bg

Austin-Vance L. (2018). Effective Behaviors Employed by Successful Teachers of Student with Learning and Emotional Challenges. Paving the Pathway for Educational Success: Effective Classroom Strategies for Students with Learning Disabilities. New York, the USA. http://www.aasep.org

Chuvasova, N. O. (2017). Pedagogical conditions of future chemistry and biology teacher's creative potential development in the process of professional training in a pedagogical university. Bulletin of the Cherkasy Bohdan Khmelnytsky National University, 7, 147152. https://cdu.edu.ua /ped-ejournarticle/view/1478

Chuvasova, N. O. (2017). Methodological approach to the research of the problem of future chemistry and biology teachers' creative potential development in higher educational establishments. In M. Koperska \& Y. Melnyk (Eds.), Psychological and pedagogical problems of modern specialist formation. Warsaw: Anagram. https://culturehealth.org/hogokz_knigi/Arhiv_DOI/08_Collected2017/18Chuvasova\%20 N.pdf

Clark-Burton, R. (2004). Sustaining Change in Universities, Continuities in Case Studies and Concepts. England: McGraw-Hill. https://doi.org/10.1080/13583883.2003.9967096

Clement, M. C. (2018). What Successful Teachers Do: A Dozen Things to Ensure Student Learning. Oxford: Rowman \& https://www.goodreads.com/book/show/38507473-what-successful-teachers-do

Dakovska, M. (2015). New technologies in teaching. Education and upbringing for tomorrow - between tradition and innovation. Sofia: St. Kliment Ohridski. https://research.unisofia.bg

Elnikova, G. V., Ryabova Z. V. (2008). Monitoring as an effective way of assessing the quality of middle-class education in the beginning. Ukraine: Obrii. http://dspace.nbuv.gov.ua/bitstream/handle/123456789/107549/8Elnikova.pdf?sequence $=1$

Fedotenko, I. L. (2007). Development of a preventive attitude of future teachers in the context of the challenges of modern society. Conditions and changes in the pedagogy of the 21st century. Sedlece, Czech Republic: Podlaski Academy. https://www.elibrary.ru/item.asp?id=26092508

Glasser, W. (1991). Schools Without Losers. Moscow, Russia: Progress. http://childpsy.ru/lib/books/id/8303.php

Ingvarson, L. (1998). Professional development as the pursuit of professional standards: the standard based professional development system, Teaching and Teacher Education. 127 (14). https://eric.ed.gov/?id=EJ568124 
Joyce, B., Calhoun, E. (2010). Models of professional development: a celebration of educators. Oxford: Corwin Press. https://www.goodreads.com/book/show/8887046-models-ofprofessional-development

Karmin A. S., Novikova E. S. (2004). Culturology. St. Petersburg: Peeters http://yanko.lib.ru/books/cultur/karmin-novikova-culturology-2006-a..htm

Kondrashov N. N., Kondrashova L. V., Chuvasova N. A., Kalinichenko N. A., \& Deforzn H. V. (2020). Development of future teachers - Strategy for improving the quality of higher pedagogical education. Brazil: Fortaleza.

Kondrashova, L. V. (2005). Preventive pedagogy. Kyiv, Ukraine: High School. http://www.irbis-nbuv.gov.ua/cgi-bin/irbis_nbuv/cgiirbis_64

Kondrashova, L.V. (2014) Pedagogy of higher education: problems, searches, solutions: Monographic essay. Cherkasy, Ukraine. http://www.irbis-nbuv.gov.ua/cgibin/irbis64r_81/cgiirbis_64

Kucheriavyi, A. O., Buryi S. V., \& Atamanchuk Y. M. (2020). Management of students' learning activities by means of distance learning: motivational aspect. Revista Inclusiones. (7). https://revistainclusiones.org/index.php/inclu

Marmaza, O. I. (2007). Management in education: Road map of a manager. Kharkiv, Ukraine: Osnova. http://repository.sspu.sumy.ua/bitstream/123456789/8526/1/Marmaza.pdf

Mason, R. (1994) Artistic achievement in Japan junior high school, Art Education, 47, 8-19. https://www.tandfonline.com/doi/abs/10.1080/00043125.1994.11652250

Nichugovska L. (2019). Pedagogical management in the formation of the creative potential of future social education in the master's conditions. Bulletin of the Cherkasy Bohdan Khmelnytsky National University, 3, 243-249. https://cdu.edu.ua

Öqvist, A., Malmstrom, M. (2018). What motivates students? A study on the effects of teacher leadership and students' self-efficiency. International Journal of leadership in Education. doi: 10.1080/13603124.2017.1355480

Panfilova, A. (2009). Innovative pedagogical technologies: Active teaching. Moscow: Academy. http://www.al24.ru/wp-content/uploads/2014/04/пан 1.pdf

Paris, G. S. (2001). The role of self-regulated learning in contextual teaching: principles and practice for teacher preparation. http://ciers.org/library/azhive/2001-04/0104parwin

Rangelova, E. (2012). The formation of a citizen and a professional - the main goal of university education. Formation of the citizen and professions in the conditions of university education. no.1. Gabrovo: Ex-Press. https://apsc-bg.eu/index.ru.php

Reisch, G., \& Flexner, A. (2017). The Usefulness of Useless Knowledge. no.20, 1083-1085. https://www.jstor.org/stable/44955591

Richardson, V. (2003). Constructivist pedagogy. Teachers College Record, 105 (9), 16231640. https://doi.org/10.1046/j.1467-9620.2003.00303.x 
Rogers K. (2004). A Look at Psychotherapy: Human Becoming. Moscow. https://www.rulit.me/books/stanovlenie-lichnosti-vzglyad-na-psihoterapiyu-read405531-1.html

Shiyanov E. N., \& Kotova I. B. (1999). Personal development in learning. Moscow. https://www.studmed.ru/shiyanov-en-kotova-ib-razvitie-lichnosti-vobuchenii_8f2b8e51399.html

Smantser, A. P., \& Rangelova, E. M. (2014). Fundamentals of preventive pedagogy. Minsk: BSU. https://elib.bsu.by/bitstream/123456789/96991/1/smancer-rangelova.pdf

Sysoeva, S. O. (2001). Creative development of personality in the process of continuing professional education. Continuing professional education: theory and practice. https://lib.iitta.gov.ua/715790/1/ПОСИБНИК\%20ТЕХНОЛОГИИ\%20\%2011.03.2019 .pdf

Toshio, N. (2008) The role of cooperative learning in the introductory stages of art teacher training programmes in Japan. International Journal of Education through Art, 14, $173-$ 176). https://core.ac.uk/download/pdf/56650085.pdf 